\title{
A Dorsal Fold in Gymnura micrura (Bloch and Scheneider, 1801) (Chondrichthyes: Gymnuridae)
}

\author{
Jorge Luiz Silva Nunes $^{1^{*}}$ and Nivaldo Magalhães Piorski ${ }^{2}$ \\ ${ }^{I}$ Centro de Ciências Agrárias e Ambientais; Universidade Federal do Maranhão; BR 222; km 4, s/n; 65500-000; \\ Chapadinha - MA - Brasil. ${ }^{2}$ Departamento de Oceanografia e Limnologi; Universidade Federal do Maranhão; Av. \\ dos Portugueses s/n; Campus Universitário do Bacanga; 65080-040; São Luís - MA - Brasil.
}

\begin{abstract}
This paper reports a dorsal fold which is a membranous structure located on the tail of two juvenile butterfly rays, Gymnura micrura (Bloch \& Scheneider, 1801), caught through artisanal fishery in the shallow waters of Maranhão State (Brazil).
\end{abstract}

Key Words: Elasmobranchii, rays, teratogeny, South America, Brazil

\section{INTRODUCTION}

The family Gymnuridae belongs to the order Rajiformes and possess two genera and fourteen species, most of them distributed in the coastal zone (Figueiredo, 1977; Compagno, 1984). In Brazil, the family is represented by two species of the genus Gymnura: G. altavela (Linnaeus, 1758) and G. micrura (Bloch and Scheneider, 1801). Both species are widely distributed throughout the coastal areas of the Atlantic Ocean with some records from the Indian Ocean. However, in this part of the world, the records of G. micrura probably refer to other species (Eschmeyer, 2004). In South America, the species seems to have a disjunct distribution, with G. micrura occurring in the north and G. altavela in the south (Figueiredo, 1977; Compagno, 1984, Humann and Deloach, 2002; Léopold, 2004; Froese and Pauly, 2007), although Menni and Stehmann (2000) and
Eschmeyer (2004) have cited G. micrura from southern Brazil.

These two Gymnura species are coastal and benthic animals of shallow waters inhabiting the sandy and muddy bottoms in estuaries and mouths of rivers. G. micrura presents a variable color pattern, with a gray, light to olive green, pink or dark brown dorsal region, with or without dispersed spots, and a white tending to yellow ventral surface. Morphologically, the species is characterized for presenting a disc width larger than the total length, reduced disc length and pelvic fins with straight margins, which in profile resembles a quadrilateral. The back, as well as the tail, is deprived of fins (Bigelow and Schroeder, 1953; Compagno, 1984).

This paper reports the occurrence of a dorsal fold (congenital disorder) located on the tail of two specimens of G. micrura caught in the Maranhão State (Brazil).

\footnotetext{
* Author for correspondence: jorge@ufma.br
} 


\section{MATERIAL AND METHODS}

Between October 1997 and February 1999, a total of $18 \mathrm{G}$. micrura rays were caught along the coast of Maranhão. During this period, the specimens were obtained in cruises of the LABOHIDRO I boat and bought from the local fisheries. The catches were performed in cruises between the depths of 8 to 25 meters using nets of 500 to 1000 fathoms, 4 fathoms long and a mesh of 8 centimeters (Stride, 1992; Nunes et al, 2005). Morphometric data were obtained using a steel pachymeter, according to Last (2004). The tails were X-rayed using the Funk 1070 odontological $\mathrm{X}$-ray equipment $(10 \mathrm{~mA}, 60 \mathrm{kV})$. The specimens were deposited in the Fish Collection of the Oceanography and Limnology Department of the Universidade Federal do Maranhão (Maranhão Federal University), under the numbers CPDOL 97610 and CPDOL 99611.

\section{RESULTS AND DISCUSSION}

From the eighteen G. micrura studied specimens, only two of them presented a dorsal fold. The anatomic formation observed corresponded to a small membranous expansion located in the middle point of the tail (Fig.1-2). This structure has nothing to do with the keel reported by Bigelow and Schroeder (1953), which is located on the upper surface of tail. The analysis of the Xray images suggested an adipose structure deprived of sustentation rays. This condition was similar to the additional structure observed by Ben Brahim and Capapé (1997), which reported a case of a supplementary dorsal fin in the ray Torpedo torpedo (Linnaeus, 1758), caught in the Tunisian Mediterranean Sea.

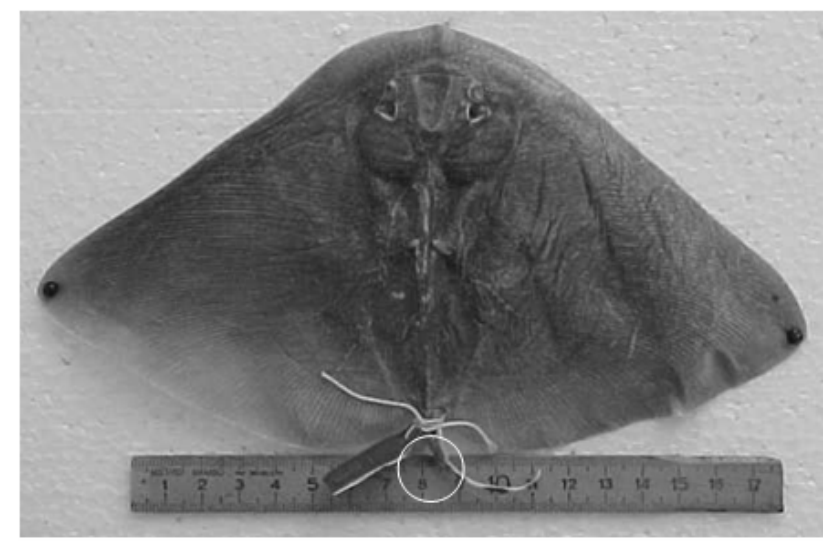

Figure1 - Specimen of G. micrura caught in the coastal region of the Maranhão State (Brazil) with dorsal fin.

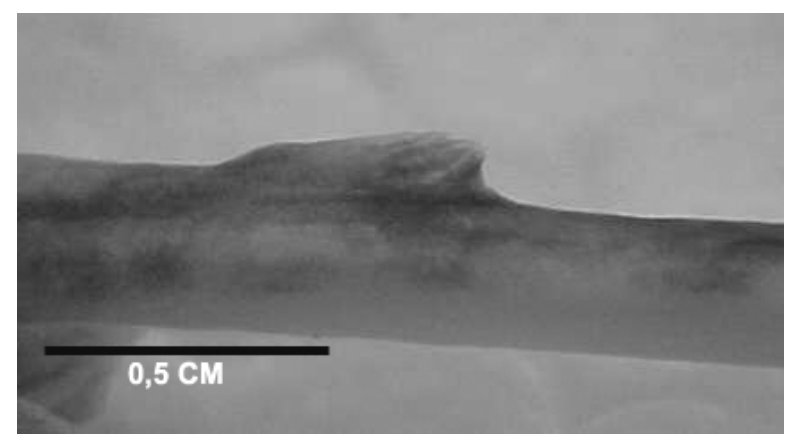

Figure 2 - Dorsal fin on the tail of a G. micrura specimen caught in the Maranhão State (Brazil). 
Old illustrations and descriptions of elasmobranchii show great morphological variations and treat as "monstrosities" the specimens that present teratogenic anomalies. (Bureau, 1890 apud Ben Brahim and Capapé, 1997). In many ray species, congenital disorders were responsible for the creation of new taxa, which were subsequently rejected after refined studies concerning their embriology (Müller and Henle, 1841 apud Rosa et al., 1996). Reporting a teratogenic structure in the fins of Potamotrygon motoro Müller and Henle, 1841, Rosa et al. (1996) observed that this anomaly did not compromise the biological activities, given that the nutritional conditions were considered normal. For the taxonomical identification of the studied specimens, morphometrics (Table 1) and morphological features presented by Bigelow and Schroeder (1953), Figuereido (1977) and Compagno (1984) indicated that all the specimens belonged to the species $G$. micrura, including the two individuals with the dorsal membranous structure.

The fold observed in G. micrura from Maranhão was probably related to some teratogenic effect or pedomorphosis process, deserving further studies in order to explain these questions.

Table 1 - Morphometric data of two specimens of G. micrura with a dorsal fold (CPDOL 97610 and CPDOL 99611) and a normal specimen $(\mathrm{X}=$ average; $\mathrm{SD}=$ standard deviation, $\mathrm{N}=$ number of individuals). Measures expressed in centimeters.

\begin{tabular}{lccccc}
\hline \multirow{2}{*}{\multicolumn{1}{c}{ Morphometric Variables }} & \multicolumn{2}{c}{$\begin{array}{c}\text { Individuals with } \\
\text { dorsal fold }\end{array}$} & \multicolumn{2}{c}{ Individuals without dorsal fold } \\
\cline { 2 - 7 } & $\mathbf{9 7 6 1 0}$ & $\mathbf{9 7 6 1 1}$ & $\mathbf{X}+\mathbf{S D}$ & $\mathbf{N}$ & Range \\
\hline Disc Width & 21.7 & 17.8 & $22.28+5.49$ & 16 & $16.0-35.9$ \\
Disc Length & 12.7 & 10.5 & $12.91+3.73$ & 16 & $8.8-22.8$ \\
Total Length & 15.9 & 14.0 & $16.75+4.89$ & 16 & $11.7-28.35$ \\
Caudal fin - Length & 4.0 & 3.8 & $4.59+1.43$ & 16 & $3.1-8.2$ \\
Interorbital Width & 2.2 & 1.9 & $2.55+0.7$ & 16 & $1.4-4.2$ \\
Distance between narial apertures - & 1.5 & 1.3 & $1.51+0.43$ & 16 & $1.15-2.5$ \\
maximum & & & & & \\
Interspiracular Width & 1.9 & 1.6 & $2.17+0.61$ & 12 & $1.6-3.5$ \\
Orbit diameter & 0.5 & 0.5 & $0.41+0.1$ & 16 & $0.3-0.7$ \\
Mouth Width & 1.7 & 1.4 & $1.78+0.62$ & 16 & $0.9-2.9$ \\
Snout to Cloaca & 10.7 & 9.4 & $10.88+3.1$ & 16 & $7.3-18.3$ \\
Snout to Mouth & 2.2 & 2.2 & $2.48+1.0$ & 16 & $1.3-5.05$ \\
Distance between $1^{\text {st }}$ and $5^{\text {th }}$ gill openings & 1.5 & 1.5 & $1.74+0.52$ & 16 & $1.1-2.9$ \\
Distance between $1^{\text {st }}-1^{\text {st }}$ gill openings & 3.4 & 3.1 & $3.59+0.93$ & 12 & $2.5-5.35$ \\
Distance between $3^{\text {rd }}-3^{\text {rdt }}$ gill openings & 3.2 & 2.8 & $3.08+0.92$ & 12 & $1.7-4.9$ \\
Distance between $5^{\text {th }}{ }^{\text {th }}{ }^{\text {th }}$ gill openings & 2.5 & 2.3 & $2.35+0.61$ & 11 & $1.75-3.7$ \\
\hline
\end{tabular}

\section{RESUMO}

Neste manuscrito registra-se uma nadadeira dorsal em dois espécimes juvenis de Gymnura micrura (Bloch and Scheneider, 1801) capturadas pela pesca artesanal em águas rasas do estado do Maranhão (Brasil).

\section{REFERENCES}

Ben Brahim, R. and Capapé, C. (1997), Nageoire dorsale supplémentaire chez une torpille ocellée, Torpedo (Torpedo) torpedo dex eaux tunisiennes (Méditerranée centrale). Cybium, 21 (2), 223-225.

Bigelow, H. B. and Schroeder, W. C. (1953), Sawfishes, Guitarfishes, Skate and Rays, Chimaeroids. In-Fishes of the Westen North Atlantic, Part II. (eds) Parr, A. E. and Olsen, Y. H., Sears Founds. Mar. Res., New Haven, pp.1-558 
Compagno, L. J. V. (1984), Sharks in the world FAO Fish Synopis, 125 (4), 655.

Eschmeyer, W.N. (ed) (2004). Catalog of fishes. California Academy of Sciences. Online version. Updated November 7, 2006.

Figuereido. J. L. (1977), Manual dos peixes marinhos do sudoeste do Brasil. Introdução: Cações, Raias e Quimeras. Museu de Zoologia da Universidade de São Paulo, São Paulo.

Froese, R. and Pauly, D. (Eds). (2007), FishBase. World Wide Web electronic publication. Disponível em: http//www.fishbase.org.

Humann, P. and Deloach, N. (2002), Reef fish identification: Florida, Caribbean, Bahamas. 3.ed. Jacksonville, Florida: New world publications, Inc

Last, P.R. (2004), Rinobatos sainsburyi n.sp. and Aptychotrema timorensis n.sp. - Two new shovelnose rays (Batoidei: Rhinobatidae) from the Eastern Indian Ocean. Rec. Aust. Mus., 56, 201-208.

Léopold, M. (2004), Guide des poisons de mer de Guyane. Ed. Ifremer.
Menni, R.C. and Stehmann, M.F.W. (2000), Distribution, environment and biology of batoid fishes off Argentina, Uruguay and Brazil. A review. Rev. Mus. Argentino Cienc. Nat., 2(1), 69-109.

Nunes, J.L.S., Almeida, Z. S. and Piorski, N. M. (2005), Raias capturadas pela pesca artesanal em águas rasas do Maranhão - Brasil. Arq.Ciên. Mar, 38, 49-54.

Rosa, R. S., Gomes, U. L. and Gading, O. B. F. (1996), Um caso de teratogenia na raia de água doce Potamotrygon motoro (Natterer in Müller e Henle, 1841) (Chondrichthyes: Potamotrygonidade). Rev. Nordest. Biol., 11 (2), 125-132.

Stride, R. K. (1992), Diagnóstico da pesca artesanal marinha do estado do Maranhão. CORSUP/EDUFMA, São Luís, 205p.

Received: April 18, 2006; Revised: May 24, 2007; Accepted: July 08, 2008. 